\title{
The Development of Discovery Learning Model With SETs Approach For Science Learning in Junior High School
}

\author{
A.N. Hidayati, Y. Riyanto, L. Nurlaela \\ Universitas Negeri Surabaya, Surabaya, Indonesia
}

\begin{abstract}
This study aimed at developing the discovery learning model with SETs approach for science learning. This research used research and development $(\mathrm{R} \& \mathrm{D})$ design proposed by Borg and Gall's model that was modified into nine steps. The subjects of the try-out were the eighth-grade students in junior high school. The data analysis was done in two ways, qualitatively and quantitatively. The results showed that the discovery learning model with SETs approach developed has five syntaxes. The learning model could be implemented in science lesson with environmental material characteristics. Some research findings showed that the discovery learning model with sets approach had met the eligibility criteria model according to Nieveen criteria. Furthermore, it successfully improved the students' learning outcomes significantly. Meanwhile, the novelty of the developed model dealt with point that the content of the material used the KTSP curriculum but the learning process used the 2013 curriculum.
\end{abstract}

\section{Keywords_-Discovey Learning; Science Learning}

\section{INTRODUCTION}

A learning model is a learning planning framework that describes the systematic procedure used as a guide in implementing a particular learning concept in order achieve the learning determined objectives [2]. According to Trianto (2007), learning model can be interpreted as a planning or pattern that is used as a guide in the planning of a learning. The learning model includes the learning approach used, the goals to be achieved, the learning stage, the learning environment, and the management. Each model requires different management systems and learning environments. Each approach assigns different roles dealing with the students, physical space, as well as the classroom social systems.

The criteria of learning models include the aspects of validity, practicality, and effectiveness [6]. A learning model is valid if it is developed based on strong theoretical rationales. The practicality aspect can be achieved if the learning model has been validated by an expert and can be applied in the field. The effective aspect can be met if it is effectively implemented in the field and be able to accomplish the learning outcomes.

A model development is defined as a conceptual design engineering in an effort to improve the function of the existing models through adding some learning components that are considered effective to improve the quality of the achievement including both the purpose of the process and the small goals. The development of a model can also be interpreted as an effort to expand or realize the potential as well as to bring a state of affairs to a state in which the stages which are more complete, greater, or better. The development is directed to a program that has been or is being implemented into a better program. It is in line with what has been proposed by Trianto (2007) that a development involves activating resources, expanding opportunities, acknowledging success, and integrating progress.

Learning models can be combined in order to achieve certain learning objectives. The success of a lesson is determined by the approach and model chosen by the teacher according to the given material, but there is no suitable learning model for all learning materials, and it should be realized that a model for achieving the goals can be incorporated in multi method (Rustaman, 2005).

The results of the interviews with the science teachers obtained information that the implementation of the learning process was done using a variety of lecturing methods (lectures, questions, and answers, discussions), in which the teachers teach based on the book package, the pursuit of the target curriculum but less attention to the students' learning needs and the learning model. The learning model used was still often dominated by teacher-centered way because the students were still difficult to actively asked questions, express opinions critically and multiply knowledge through learning their discoveries by relating it with technology and environment around. Therefore, the materials presented were obtained by the students in the realm of memorization, not as an understanding of the concepts studied. It is supported by the data on the results of student need analysis showing that $56.25 \%$ of the students stated that they were learning science through memorizing. As a result of not applying the appropriate learning model in accordance with the needs of students, the quality of the natural science learning was still not low. This condition is also relevant with TIMSS 2015 results. For the first time, Indonesia participated in a four-year survey in assessing the ability of Mathematics and Science students of the fourth grade elementary school. During this time the students included were the eighth-grade students. Indonesia went back to the bottom scores on Science, 397 in 45 th place from 48 countries. To improve learning and achieve the objectives that have been 
mentioned above, the researchers offer an integrated learning discovery learning model environment, namely the discovery learning model with SETS approach. This model is the result of a developmental study conducted through an adjustment of development model in R \& D model developed by Borg \& Gall (1993) with the aim of testing whether the model developed can improve student learning outcomes. This study aimed at developing discovery learning model with SETs approach for science learning.

\section{A. Discovery Learning}

Discovery learning is a learning that puts students in a variety of situations, questions, or activities that guide students to discover the concept independently. The learning process takes place when students build and connect new information that has been discovered with information that students already have. The experience that students got directly can make them easier to learn and recall information (Wilke \& Straits, 2001).

The activities in discovery learning include exploration activities where the teacher plays a role of asking questions and problems to be solved by the students, as well as introducing concept dealing with collecting information related to the student experience. Furthermore, it also deals with the teacher concept application to expose the students into new situations based on the exploration and concept application [1]. There are several steps that have to be taken in implementing the discovery model according to Veermans (2002). The steps are orientation, hypothesis generation, hypothesis testing, conclusion, regulation, planning, monitoring, and evaluation.

\section{B. SETS approach}

The SETS approach provides students with knowledge which is appropriate to their level of education. The content of SETS in education is in line with the targeted educational outcomes. The exact focus of SETS in the discussion concerns on the relationship between the topic of the discussion with the students' daily life. It means that aspects related to student's life should be taken into account. The objective of SETS is encouraging students to have an inquiry in gaining knowledge related to the science lesson, the environment, the technology, and the people involved.

The steps of the community science model developed by Poedjiadi (2005) are arranged as follows: (1) preliminary/initiation/apperception stage, (2) the concept formation/development stage, (3) the application stage of the concept in life or problem-solving analysis, and (4) concept stabilization stage.

\section{METHOD}

\section{A. Research Design}

This research uses research and development method or known as R \& D (Research and Development). The research was done according to Borg \& Gall's (1989: 784-785) concept which consists of ten steps of implementation of research and development strategy. To know whether the model used in this research is successful, a research procedure referring to Borg $\&$ Gall (1983) was used. The procedure includes: (1) research and information collection; (2) planning; (3) developing preliminary form of the product; (4) preliminary field try out; 5) main product revision; 6) main field try out; 7) operational product revision; 8) operational field try out; 9) final product revision; and (10) dissemination and implementation. However, in this study, there were only 9 steps conducted leaving the last step of the whole procedure.

\section{B. Subjects}

Open Subjects in a limited field trial were ten grade VIII students in the Olympic class at SMPN 1 Kebomas (other than those used for operational field testing). Subjects in this field trial are all students of grade VIII SMPN 1 Kebomas. The operational field tests were carried out using a DLPSETS model treated class. Subjects in field trial were 32 students of class VIII-G.

\section{Instruments}

TABLE I. INSTRUMENTS OF DATA COLLECTION

\begin{tabular}{|c|c|c|c|}
\hline Stage & Data & $\begin{array}{l}\text { Data Collec- } \\
\text { tion }\end{array}$ & Technique \\
\hline $\begin{array}{l}\text { Needs analy- } \\
\text { sis }\end{array}$ & $\begin{array}{l}\text { The applicable } \\
\text { curriculum }\end{array}$ & & Documentation \\
\hline & $\begin{array}{l}\text { Early learning } \\
\text { outcomes }\end{array}$ & & \\
\hline & Devices used & & \\
\hline & $\begin{array}{l}\text { The initial con- } \\
\text { dition of the } \\
\text { and learning } \\
\text { activities }\end{array}$ & $\begin{array}{l}\text { Observation of } \\
\text { teaching and } \\
\text { Learning activ- } \\
\text { ities }\end{array}$ & Observation \\
\hline & Models used & $\begin{array}{l}\text { A list of ques- } \\
\text { tions as guide- } \\
\text { line }\end{array}$ & Interview \\
\hline & Students' needs & $\begin{array}{l}\text { Students' } \\
\text { opinion in the } \\
\text { answers of the } \\
\text { questionnaires }\end{array}$ & Questionnaire \\
\hline \multirow[t]{2}{*}{ Initial Test } & $\begin{array}{l}\text { Validity model } \\
\text { and supporting } \\
\text { devices }\end{array}$ & $\begin{array}{l}\text { Model valida- } \\
\text { tion sheet }\end{array}$ & Questionnaire \\
\hline & & $\begin{array}{l}\text { Validation of } \\
\text { learning tools } \\
\text { supporting } \\
\text { models (lesson } \\
\text { plans, student } \\
\text { worksheets, } \\
\text { student text- } \\
\text { books) }\end{array}$ & \\
\hline
\end{tabular}




\begin{tabular}{|c|c|c|c|}
\hline & & $\begin{array}{l}\text { Test validation } \\
\text { sheet of the } \\
\text { learning result }\end{array}$ & \\
\hline \multirow[t]{2}{*}{$\begin{array}{ll}\text { Field } & \text { Test } \\
\text { Limit } & \end{array}$} & $\begin{array}{l}\text { Representative } \\
\text { information }\end{array}$ & $\begin{array}{l}\text { Review of the } \\
\text { learning devic- } \\
\text { es }\end{array}$ & Questionnaire \\
\hline & & $\begin{array}{l}\text { Readability of } \\
\text { the student's } \\
\text { worksheet and } \\
\text { student's text- } \\
\text { book }\end{array}$ & \\
\hline \multirow[t]{5}{*}{$\begin{array}{l}\text { Field } \quad \text { Test } \\
\text { Operations }\end{array}$} & $\begin{array}{l}\text { The practicality } \\
\text { of the learning } \\
\text { model }\end{array}$ & $\begin{array}{l}\text { Observation } \\
\text { sheet of the } \\
\text { implementation } \\
\text { of the learning } \\
\text { model }\end{array}$ & Observation \\
\hline & & $\begin{array}{l}\text { Observation } \\
\text { sheet of the } \\
\text { implementation } \\
\text { according to } \\
\text { the lesson plan }\end{array}$ & \\
\hline & $\begin{array}{l}\text { The effective- } \\
\text { ness of the } \\
\text { model }\end{array}$ & $\begin{array}{l}\text { Observation } \\
\text { sheet of student } \\
\text { activity }\end{array}$ & \\
\hline & & $\begin{array}{l}\text { Test of science } \\
\text { learning to get } \\
\text { the outcomes }\end{array}$ & Written test \\
\hline & & $\begin{array}{l}\text { Questionnaire } \\
\text { student to get } \\
\text { the students' } \\
\text { responses }\end{array}$ & Questionnaire \\
\hline
\end{tabular}

\section{Data Analysis}

The results of cognitive learning are shown in the form of N-Gain (normalized gain) according to Hake (2002). Descriptive analysis of $\mathrm{N}$-gain was done using $\mathrm{N}$-gain criterion according to Hake (1999) which includes: (1) learning result outcomes with "high achievement" if $<\mathrm{g}>\geq 0.7$, (2) learning outcomes with "medium achievement" if $0.3 \leq<\mathrm{g}><0.7$, and (3) learning outcomes with "low achievement" if $\langle\mathrm{g}\rangle\langle 0.3$. Basically, the use of $\mathrm{N}$-gain is to determine the category of learning outcome improvement which are classified into high, medium, or low categories as recommended by Hake (1999). Besides, the descriptive analysis uses $\mathrm{N}$-gain to know the significance of improvement of learning result through comparing the preliminary and final test (pretest and posttest) results by using paired sample t-test.

\section{RESULTS AND DISCUSSION}

\section{A. Validity}

The validation result of the learning model done by 3 experts who conclude, from the result of the data analysis of content and construct validity model developed, that the learning model had fulfilled all the validity criteria. It means that the model developed had a strong theoretical basis and there is consistency among the components in it. These results were in line with the validation results of model support devices in which the average total of data aspects given by the experts and practitioners of learning devices supporting the model had met the criteria. Therefore, it can be concluded that the assessment of experts and practitioners stated that the learning model was valid, yet it needed to do some small revisions.

\section{B. Practicality}

The observation of the model component shows that the total average score given by the two observers was 1.86 while the two observers agreed that the DLPSETS model component implemented gained good percentage of agreement $(\mathrm{PA})=$ $86.38 \% \geq 75 \%$ (reliable). Moreover, it is confirmed by the implementation criteria which required that the model component was fully executed $(1.5 \leq \mathrm{X} \leq 2.0)$.

The average value of the teachers' ability to manage to the learning process was in the range of 3.75-3.93 which is categorized "very well" $(3.00 \leq \mathrm{TKG} \leq 4.00)$. The teachers had no difficulty in applying the learning model in the classroom.

\section{Effectiveness}

The descriptions related to student learning outcomes were done in two ways, using N-Gain and paired t-test. The use of $\mathrm{N}$-Gain was to find out the categories of improved learning outcomes. Meanwhile, the use of paired t-test was to know the significance of the of preliminary and final test (pretest and posttest) results.

From the calculation of the results, it was obtained that the average increase in student learning outcomes was $70 \%(\mathrm{~N}$ gain of 0.70). Based on the criteria proposed by Hake (1999), $\mathrm{N}$-gain of 0.70 is included in the category of high improvement [5]. Thus, in terms of the students' learning outcomes, this model was considered affective. It means that applying this model for eighth-grade students in science would lead to a positive impact of improving their learning outcomes.

A summary of the paired t-test results is presented in Table 2. The results of the experiment test the difference of the learning outcomes in the initial test and final tests through the help of SPSS 21.0.

The significant value (2-tailed) range is $0,000<0.01$. Since the significant value (2-tailed) of 0.000 is smaller 0.01 , it could be concluded that the use of the model could improve the science learning outcomes of the eighth graders of SMPN 1 Kebomas significantly with $\alpha=0.01$.

TABLE II. SUMMARY OF T-TEST RESULTS WITH PAIRED PRETEST AND POST-TEST

\begin{tabular}{|l|c|l|l|}
\hline \multicolumn{1}{|c|}{ Class } & \multicolumn{1}{|c|}{ T } & \multicolumn{1}{c|}{ df } & \multicolumn{1}{c|}{ Sig.(2-tailed) } \\
\hline VIII-G & $-38,844$ & 31 & 0,000 \\
\hline
\end{tabular}




\section{CONCLUSION}

From the research results, it can be concluded that the model developed by following the concept of Borg and Gall (1983) model. This research resulted a product which consists of some models that have been developed through the steps of the procedure. The product then was validated by three validators. The result of the field test showed that the product had met the criteria of practicality and effectiveness. In terms of the improvement of learning outcomes, this model can be used in science learning dealing with materials about environmental characteristics.

In relation to the content validity, the novelty of this discovery learning model covers the existence of the application phase dealing with concept in life encouraged the students to think creatively about the concept that they had understood in the previous activities. Therefore, it could help the students to develop the attitude of critical thinking and attitudes toward the environment which becomes one aspect of the scientific attitude proposed by Harlen (1996). It is line with the purpose of science lesson showed by point 3 listed in Permendiknas no. 22 of 2006.

Another novelty of this model was also dealing with the implementation of the 2013 curriculum. In this case, the model developed was a model, content material of which was taken from the KTSP 2006 document but wrapped in the learning activities according to the 2013 curriculum. It could be seen from the selection that the discovery learning model is one of the learning models presumed to be used in the 2013 curriculum where the learning process needs to be scientific. In addition, the scientific attitude is also considered as an aspect developed in the learning process of 2013 curriculum. Therefore, the developed learning model can also be used in the 2013 curriculum in all the first-year classes at any schools.

\section{REFERENCES}

[1] J. Abruscato, Teaching children science: a discovery approach. United State of America: Allyn and Bacon. 1995.

[2] Amri, K.I. Ahmadi Proses Pembelajaran Kreatif dan Inovatif Dalam Kelas. Jakarta: Prestasi Pustaka Raya, 2010.

[3] J. A. Castronova, Discovery learning for the 21 century: what is it and how does it compare to traditional learning in the 21 st century. Diperolehdari website: http://chiron.valdosta.edu/are/Litreviews/vol1no1/castronova_lit. 2002.

[4] R. R. Hake, Design-based research in physics education: A review, hlm.1-24, 1999.

[5] W. Harlen, Teaching and learning primary science.London: Paul Chapman Publishing, 1996.

[6] N. Nieveen, Prototype to reach product quality, dalam Van Den Akker, J., Branch, R.M., Gustafson, K., Nieveen, N., \&Plomp, T. (pnyt.). Design approaches and tools in educational and training. Dordrecht: Kluwer Academic Publisher, 1999. 